\title{
Modelling the proximate determinants of fertility for Brazil: the advent of competing preferences
}

\author{
Raquel Zanatta Coutinho* \\ Andre Braz Golgher ${ }^{\star *}$
}

More than half of the world's population lives in a country where fertility is below replacement level (MYRSKYLA; KOHLER; BILLARI, 2009). In Brazil, the total fertility rate (TFR) went down from 4.26 children per women in 1980 to 1.91 in 2010 . Some internal disparities exist. We use data from the DHS from 1986, 1996 and the PNDS from 2006, the most recent survey available, to decompose and analyze fertility rates using a framework proposed by Bongaarts (2001), which is especially useful to explore and compare factors behind total fertility rates. The framework includes desired family size (DFS), unwanted fertility, sex preference, replacements for child mortality, rising age at childbearing, involuntary infertility and competing preferences. By understanding fertility components across time in Brazil, this paper illuminates how these factors vary by socio-demographic characteristics (race, religion, wealth, education, and place of residence), and how these factors combined have formed TFR throughout the years and in contexts of both high and low fertility. We found that, contrarily to what happened in the past, women in recent periods are having, in aggregate, fewer children than their ideal family sizes. However, unwanted pregnancies still explain why certain social groups have more children than desired. We also find that women with higher levels of education tend to desire more children than women with lower educational levels. Competing preferences is the main explanation for this disparity.

Keywords: Below replacement fertility. Decomposition. Proximate determinants. Brazil.

\footnotetext{
* Universidade Federal de Minas Gerais (UFMG), Centro de Desenvolvimento e Planejamento Regional (Cedeplar), Belo Horizonte-MG, Brazil (quelzanatta@gmail.com; https://orcid.org/0000-0002-2841-1480).

** Universidade Federal de Minas Gerais (UFMG), Centro de Desenvolvimento e Planejamento Regional (Cedeplar), Belo Horizonte-MG, Brazil (agolgher@gmail.com; https://orcid.org/0000-0001-5884-225X).
} 


\section{Introduction}

Historically, policymakers in developing countries were concerned about how high fertility rates contributed to rapid population growth and to poor urban and socioeconomic conditions (BONGAARTS, 2001). Today, low fertility is a widespread phenomenon, also occurring in many developing countries. Half of the world's population lives in a country where fertility is below replacement level (UNITED NATIONS, 2017). Brazil is now one of them as well (CARVALHO; BRITO, 2005; POTTER et al., 2010). The total fertility rate (TFR) went down from 6.2 children per women in 1940 to 1.9 in 2010 in Brazil (IBGE, 2012). Some internal disparities exist, however, regardless of the low value at the aggregate level and despite the general decline. For example, in 2010, while TFR was 1.24 children per women for those with more than 12 years of formal education, those who had between 0 and 3 years of education had a TFR of 3.14 children. For more information on Brazil's fertility decline, see Carvalho and Brito (2005), Alves and Cavenaghi (2009), Miranda-Ribeiro and Garcia (2012) and Cavenaghi and Berquo (2014).

As observed empirically, at the beginning of the fertility transition, fertility rates are usually higher than desired family sizes (BONGAARTS, 2001). Societies undergoing fertility transition tend to witness, as the transition unfolds, a reversal of this relationship. Thus, in developed countries it is common to find that desired family size (DFS) is higher than TFR (BONGAARTS, 2001; BACCI, 2001). Scholars want to explore the observed variations in desired fertility to understand if people are able to implement fertility preferences.

In high fertility contexts, this investigation is an important step for sexual and reproductive health research and policy because desired fertility is the most important factor behind theories of fertility transition as well as for measuring the scope of unwanted fertility, especially the unmet need for contraception (BUSHAN; HILL, 1995; MASON, 1997). On the other hand, in low fertility contexts, much of this decline in fertility levels might actually be an effect of the postponement of fertility, as argued by Bongaarts and Feeney (1998), the so-called tempo effect. If this is true, one might see recuperations in fertility rates in the future, when women stop further postponement (MORGAN, 2003). Nevertheless, research shows that changes do not seem to be only a timing effect, but a reduction in the number of births, which can have severe implications for the "lowest-low" fertility countries (MYRSKYLA; KOHLER; BILLARI, 2011). In both scenarios, understanding how fertility rates behave is important for projecting fertility rates into the future assuming that women, in general, are improving their capacity of planning their births.

In order to investigate what factors have contributed for the composition of the TFR over the years, in its transit from high to medium and then from medium to below replacement levels, we explore Brazil through the lenses of a framework devised by Bongaarts (2001). This framework decomposes fertility rates into six factors: unwanted fertility, sex preference, replacements for child mortality, rising age at childbearing, involuntary infertility and competing preferences. Put together in a simple equation, these six parameters enhance 
or decrease actual fertility when compared to desired fertility. The model is also useful to explain variability among social groups, or what "constrains" behavior explaining fertility trends and differentials, and to explain the disparity between observed fertility and DFS (DHARMALINGAM; RAJAN; MORGAN, 2014).

This framework has been previously operationalized empirically by Dharmalingam, Rajan and Morgan (2014), who estimated parameters for India using Demographic Health Survey (DHS) data from three consecutive surveys. We follow their methodology, slightly modified in this paper in order to adjust it to the Brazilian reality. As opposed to Brazil, India has a context of universal marriage. Thus, the competing preferences parameter in Dharmalingam, Rajan and Morgan (2014) is set to be null because it does not cause any effect on fertility rates - since all women eventually marry and have children. In the context of Brazil, however, where the mean age at first union was 23.9 in 2000 increasing to 24.6 in 2010 (VIEIRA; ALVES, 2016) the competing preferences factor is expected to assume a positive result and to deflate fertility rates as women may be choosing to pursue career or other life goals in lieu of becoming mothers.

Factors associated with a disparity between intentions and behaviors, at the aggregate level, could be different for each country or social group, and the degree of change over the years might hide internal disparities. The substantial differences in the countries' fertility transition makes studying low fertility in Brazil an opportunity to understand how interactions and changes in social institutions and in preferences shape Brazil's fertility. Moreover, it is possible that two social groups with the same TFR could have different values for the same parameters. This could help policy makers identify priorities and make informed decisions when planning sexual and reproductive health policies.

This paper is a methodological exercise to explore fertility variation and its components across time in Brazil, shedding light on the factors that form fertility rates in contexts of high and low fertility and how they have contributed for the reversal in the relationship between DFS and TFR over the years. After decomposing the parameters, it will be possible to understand how much of the decrease in TFR in Brazil is a change of preference possibly driven by ideational changes surrounding the meaning of childbearing, reflected in desire for smaller family sizes or an inability of women to fulfill their reproductive expectations, or both. We will also be able to see how the importance of each parameter changes according to the years. We use the Demographic and Health Survey (DHS) database from 1986, 1996, and the Pesquisa Nacional de Demografia e Saúde (PNDS) from 2006 to decompose TFR into the parameters for each year and by socio-demographic groups separately (race, religion, education, wealth and place of residence).

\section{Theoretical and methodological frameworks}

The proximate determinants of fertility are the biological and behavioral factors through which social, economic and environmental variables, the so-called "indirect" or 'distal' 
determinants, affect fertility (BONGAARTS; POTTER, 1983, p. 1). Generally, these factors assess fertility in an environment where regulation is deliberately practiced, the fertility rates thus departing from natural fertility. They were first described in a theoretical paper by Davis and Blake (1956) and further developed by Bongaarts (1978), the first to introduce measurements to proximate determinants. Bongaarts and Potter (1983) conceptualized TFR as being a result of natural fertility, multiplied by four parameters that would decrease it. The first parameter is age at first marriage, which identifies the onset of exposure to the risk of socially sanctioned childbearing. This rate is affected by the mean age at marriage, existence of marital dissolution, and proportion of the population who ever marries. In countries such as in Brazil, where parenthood is not tied to marriage, women are at risk of getting pregnant as soon as they become sexually active or during cohabitation (BERQUO; GARCIA; LIMA, 2012). The second parameter is contraceptive use. The prevalence, type and effectiveness of the method will affect fertility because some are more effective than others, usually depending on the amount of human action needed before the sexual act. Thus, changes in the pattern of contraceptive behavior with age, time, and cohort will likely have an impact. Rate of induced abortion is the third parameter. Note that abortion will not only prevent birth, but will make women return to ovulation quicker, so abortions do not avert a full birth at population level. Duration of postpartum infecundability is the fourth parameter, which is estimated based on the duration of breastfeeding.

When fertility control is reasonably well established, factors such as marital fertility or duration of breastfeeding are no longer important. A new equation was put together in Bongaarts (2001). We will refer to this approach and conceptual framework as Proximate Determinants of Low Fertility (PDLF) (BONGAARTS, 2001). It has been especially useful for mapping the factors enhancing or reducing fertility relative to desired family sizes (MORGAN; HAYFORD, 2009), or, in other words, factors that make a social group have more children than those initially desired and factors that keep fertility rates lower than desired.

Measuring the distance between intended and realized fertility is important for policymaking because desired fertility is the most important factor behind theories of fertility transition and for measuring the size of unwanted fertility, especially the unmet need for contraception (BUSHAN; HILL, 1995). It is also important for projecting fertility rates into the future.

The first group of factors is composed of additional or surplus fertility due to unwanted fertility $\left(\mathrm{F}_{\mathrm{U}}\right)$, sex preference (the enhancing effect on fertility due to not achieving the desired sex composition of the children, $\mathrm{F}_{\mathrm{SP}}$ ), and replacements for child mortality (physiological replacement, volitional replacement or hoarding, $\mathrm{F}_{\mathrm{R}}$ ). The second group is composed of rising age at childbearing (tempo effect, which would be the effect of the increasing mean age at childbearing on fertility rates, $\mathrm{F}_{\mathrm{T}}$ ), involuntary infertility (or inability to conceive or produce a live birth, $\mathrm{F}_{\mathrm{I}}$ ), and competing preferences for motherhood (the decreasing effect on fertility because of factors such as acquiring higher levels of human capital, not finding a suitable partner or by focusing in labor market outcomes, $\mathrm{F}_{\mathrm{C}}$ ). 
The equation is as such:

$T R F=D F S^{\star}\left(F_{U}^{\star} F_{S P}{ }^{\star} F_{R}\right)^{\star}\left(F_{T}^{\star} F_{I}^{\star} F_{C}\right)$, where $F_{U}, F_{S P}, F_{R} \geq 1$ and $F_{T}, F_{I}, F_{C} \leq 1$

In the equation above, when factors help to increase fertility related to desired family size, the parameters take values higher than 1 . When they are impacting negatively (deflating), they take values below 1 . The most powerful the parameters shaping fertility level, the further they are from the unity (1).

Some of those parameters are expected to stand out in the Brazilian case, while other are not expected to have a higher value. Unwanted fertility, for example, is expected to be an important determinant. Curtis (2012) evaluated Brazil's contraceptive use and concluded that despite the near universality of contraceptive use, $29.7 \%$ of births in the five years before the 2006 PNDS were reported as mistimed (wanted later) and $17.8 \%$ were reported as unwanted (BRASIL, 2008), confirming that this would be an important determinant. In a similar vein, Lacerda et al. (2005) found evidence of unmet need for contraceptive in Brazil in the year 2002. This pattern is commonly found in other low fertility countries, which is a sign of contraceptive failure and inconsistent contraceptive use (CLELAND, 2004).

Sex preferences are not expected to be as high as in India, as found by Dharmalingan, Rajan and Morgan, (2014). In contexts of low fertility, not many people will continue having more births just to achieve a preferred gender composition. In some social contexts, this "intensification" of sex preference might encourage sex-selective abortion, which could allow women to achieve both low fertility and a preferred gender composition. Nonetheless, although the number of abortions is quite high, yet restricted and forbidden (DINIZ; MEDEIROS, 2010), this is not the case in Brazil, as it is not sex selective. According to Dharmalingan, Rajan and Morgan (2014), in traditional patriarchal institutions (e.g., India), sons are valued more than daughters for their greater economic utility and due to sociocultural logic. In Latin America, as emphasized by Bongaarts (2001), this effect might be smaller, even favorable to females, or tend to a gender balance. In fact, Souza, Rios-Neto and Queiroz (2011) found evidence that the probability of having a third child is higher for women whose first two children had the same sex.

The tempo effect is expected to impact. That is because, unlike in Europe, tempo effects in Brazil might be negative, inflating TFR due a declining mean age at childbearing, which fell from 29.5 in 1970 to 26.5 in 1994 (MIRANDA-RIBEIRO; RIOS-NETO; CARVALHO, 2013; ALVES; CAVENAGHI, 2009; MIRANDA-RIBEIRO; ORTEGA; RIOS-NETO, 2006; RIOS-NETO et al., 2005). This decline was mainly caused by a reduction in fertility rates at older ages drove by women who had children at an early age and either postponed the next child or averted fertility after an early onset. This fact is even considered an idiosyncrasy of the Brazilian fertility transition who is able to combine low mean age at childbearing with low fertility rates. Thus, although equation parameters expect tempo effects do deflate fertility, in Brazil, just the opposite might have happened in the last decades of the $20^{\text {th }}$ century. Nevertheless, the mean age of childbearing has increased modestly in the last decade (MIRANDA-RIBEIRO; GARCIA, 2012). Nowadays, the mean age at childbearing in Brazil is of 26.7 while in most developed countries 
it surpasses 30 (UNITED NATIONS, 2017). Drawing on Lesthaegue and Willems (1999), and after observing postponements for the second child, Miranda-Ribeiro and Garcia (2012) even suggest that Brazil is entering the second demographic transition, where after fertility levels decline for all ages and parities, women start postponing fertility. In this case, for more recent decades, the tempo effect might have become positive.

Competing preferences interfere with a women ability to have the children she desired and that negatively affect her maternity prospects (BACCl, 2001). For example, women who work and have to invest in their careers sometimes need to avoid motherhood in order to advance at work. Other factors such as higher education aspirations and the pursuit of other life goals are also examples of situations women not always anticipate when planning their DFS (BACCl, 2001). Although the wording "preference" makes it sound like women are happily choosing a new plan over the old one, this is not always true. Prolonged singlehood, inflexible work schedule, lack of affordable childcare are other situations which might make a woman think twice before having a first or an additional child.

Competing preferences seem to be an important factor shaping Brazilian fertility rates. Paulo (2012) models the female hourly wage comparing mothers and non-mothers. Independent of education, non-mothers had much higher wage, and the difference is higher for women of high education, which suggest that the penalties and cost of opportunities is higher for these women. Dias Júnior (2008) found associations between occupation and fertility. Women who worked in managerial positions and/or who held a bachelor degree tended to postpone fertility. Conversely, women with low skill occupations tend to have a more "flexible" relationship with work, with worse pay and no benefits or formal work contract. In those types of jobs, wages do not improve with experience, so women can leave for maternity and return with apparently low penalty to their careers. In addition, women have recently increased their rates of participation in the labor market in Brazil, and have also been more economically responsible for households (ITABORAI, 2003), implicating in higher levels of competing preferences. Souza, Rios-Neto and Queiroz found that children substantially decrease a women's participation in the labor market in Brazil.

Contrarily to unwanted fertility $\left(\mathrm{F}_{\mathrm{U}}\right)$, rising age at childbearing $\left(\mathrm{F}_{\mathrm{T}}\right)$, and competing preferences $\left(\mathrm{F}_{\mathrm{C}}\right)$, we do not expect the parameters of sex preference $\left(\mathrm{F}_{\mathrm{SP}}\right)$, replacements for child mortality $\left(\mathrm{F}_{\mathrm{R}}\right)$ and involuntary infertility $\left(\mathrm{F}_{\mathrm{I}}\right)$ to stand out. In the next paragraphs, we will explain how each of the parameters are estimated. Additional information on conceptualization, limitations and considerations can be found elsewhere (COUTINHO, 2016).

\section{Data and measurements}

\section{Data}

We used data from the two most recent waves of the Brazilian Demographic and Health Survey (DHS) of 1986 and 1996 and from the Pesquisa Nacional de Demografia e Saude (PNDS) of 2006. The databases of 1996 and 2006 are nationally representative, 
cross-sectional, and have the following sample sizes: 12612 and 15575 . The database from 1986 is not nationally representative because it excluded four states in the North region, as well as rural areas in five other states. According to the 1980 Census, those areas represented less than $5 \%$ of the Brazilian population at the time and were excluded due to the difficulties in accessing the households (BEMFAM, 1987). Besides, two states of the Northern region were grouped into Center-West (Amazonas and Pará). The small Federal District was also included in the Southeast, although it should have been part of the Center-West. The sample size equals 5892 and it only contains four major regions, South, Northeast, Southeast and Center-West, which thus must be analyzed with caution.

Sample sizes are statistically determined by the level of precision needed at the strata level. They were calculated based on the most recent population count at the time of the survey implementation.

Although the PNDS is not identical to a DHS, it contains many of the same questions needed to decompose fertility rates. Unfortunately, the Pesquisa Nacional de Saúde (PNS), conducted in 2013, does not contain all the necessary questions to address the determinants and thus could not be used.

The DHS and the PNDS programs have developed standard procedures, methodologies, and manuals to guide the survey process and make countries and years comparable (CAVENAGHI, 2009). Sample procedure for the DHS and the PNDS followed specifications of the equal probability of selection method (EPSEM) and the probability proportion to size (PPS). Due to these complex sampling designs, we utilized women sample weight combined with the cluster sampling to account for different probabilities of selection. Original survey databases and methodology are publically available (BEMFAM, 1987, 1997; BRASIL; CEBRAP, 2009).

We focus on women of reproductive age (15-49) and their children born in the last 3 years, following Dharmalingam, Rajan and Morgan (2014). Missing data for covariates were treated as Missing Completely at Random and deleted from the analytical sample.

Total fertility rate (TFR)

To estimate TFR, we calculated the fertility rates of the last 3 years preceding the surveys. The number of children born in the last 36 months is divided by the women-years lived of exposure age 15-49 by 5 year age group interval. We used the Century Month Code technique to account for women who were part of two different age groups in the triennial.

Desired family size (DFS)

Although Bongaarts conceptualized DFS as the desire of the couple, the Brazilian data only ask this question to women. DFS is conceptualized as "target fertility" and is measured by the response given to the following questions, which are different for women who had and had not had any children yet, respectively: "if you could go back in time to the time when you did not have any children and could choose the number of children you could 
have throughout your whole life, what number would it be?"; and "if you could choose the exact number of children to have throughout your whole life, what number would it be?". The desired number of children reported by all women was averaged and the result stands as the DFS. ${ }^{1}$

Target fertility measured as above contains important limitations, addressed by Bushan and Hill (1995). The first limitation is ex-post rationalization. Couples who already have children might feel bad to report their existing children as unwanted. A second limitation is that interviewees might not understand if the question refer to "all conditions being the same" or "in an ideal world". Those two interpretations might yield different children quantities. A third limitation is that couples who have lost children might incorporate extra children in their calculations because they know death can be expected. Beyond the fourth limitation, which are the non-numeric answers, such as "up to God", many other can be found in the literature.

In spite of the limitations, the DFS utilized in this article is the best that we have available (see VIGNOLI; CAVENAGHI, 2017 for a review) and a more recent study verified the statistical accuracy of the measurement of fertility preferences to determine intention (fertility behavior) (RYBINSKA, 2016). Other studies that were modeling desired fertility over time, longitudinally, are surprised by the fact that "desired fertility" is rather constant over time in the aggregate level, since some people miss their target low and other miss it high (QUESNEL-VALLEE; MORGAN, 2003; MORGAN; RACKIN, 2010; RAY; HARCEY; TIEMEYER, 2016). As Dharmalinghan et al. (2014) explains, micro level variation in individual measures of fertility intentions are common because fertility decisions are a product of interactions and are a dynamic decision making process (JOHNSON-HANKS et al., 2011). However, aggregate level measures, such as the one this article utilizes, is linked to macro-social environments, or the influence of social structure, moving "away from individual decision (what happens in the brain) to the structures in the world motivating and constraining behavior" (BACHRACH; MORGAN, 2013 apud DHARMALINGHAN et al., 2014, p. 1453).

\section{Unwanted fertility $\left(F_{U}\right)$}

When estimating unwanted pregnancy, ex post rationalization of children might happen due to the stigma associated with reporting a child as unwanted (DHARMALINGAM; RAJAN; MORGAN, 2014). The strategy used was to consider the birth of a living child in the last 36 months where the woman responds that prior to getting pregnant she wished to have no

\footnotetext{
${ }^{1}$ Measuring retrospective desired fertility with cross sectional data started in the 1940 in the United States. Around the world, the Word Fertility Survey (1970s-1980s) and the Demographic Health Surveys (from 1980s on) are the two surveys which attempted to capture this stance maintaining worldwide comparability. These two surveys have also helped develop new ways to capture desired family size. One example is by deleting the children reported to be unwanted. Nevertheless, this method does not resolve ex-post rationalization. Another one is to ask women "would you like to have another child?". The problem with using desire for additional children as a measure is the fact that it remains impossible to know whether women who do not want more children, had unwanted children in the past. If we still had that data, ex-post rationalization could still operate.
} 
more children, as unwanted. The ratio of unwanted children born in the last 3 years to all children born in the last 3 years is added to 1 to be transformed into the first parameter Fu.

Bongaarts and Potter model (1983) included abortion as an important determinant of fertility, but in the PDLF model, abortion is no longer a separate determinant because in developed countries, contraceptive use among women trying to avoid pregnancy is close to perfect and abortion is safe, legal and less sizable. Unwanted births are those unwanted among births that actually occurred. Therefore, high abortion levels might decrease fertility and unwanted births because we can assume all aborted births were unwanted pregnancies that did not produce live births. Likewise, maternal death from abortion will eliminate the women from both the numerator and the denominator in a household survey. Successful abortions will lead to no children ever born. Unsuccessful abortions, or lack of access to abortion, on the other hand, will lead to the birth of a supposedly unwanted child, increasing the indicator of Unwanted Fertility. So, although aborted births form a large part of pregnancies in Brazil, ${ }^{2}$ those are ignored by the equation as a single parameter. Yet, children who were supposed to be aborted or averted will inflate the parameter of Unwanted fertility.

When interpreting the $\mathrm{Fu}$, it is necessary to bear in mind that these rates could be lower had the contraceptive use been more efficient and abortion been safer and legal. It is also worth mentioning that the lower rates of unwanted births for some social groups in comparison to others could actually signalize better abortion access for some social groups and worse access for others.

Sex preference $\left(F_{S P}\right)$

Parents may prefer a family of a particular size and sex composition. If the number of children is achieved but the composition is not, parents may continue to have births, therefore leading to higher fertility than initially desired (BONGAARTS, 2001).

In the Brazilian DHS $(1986,1996)$ and PNDS (2006), women reported the exact number of sons and daughters they would like to have in an ideal situation. Technically, this would be a good indication of sex preference; however, because desire does not always translate into accomplishments, and because there could be ex post rationalization, observed parity progression is a better indicator of the impact of sex preference on fertility in societies where the figures of selective abortion are small (BONGAARTS, 2013). Parity progression shows if the progression to the next birth depends on the sex composition of preceding births, a proxy for sex-selective stopping behavior.

We followed the methodology proposed by Dharmalingam, Rajan and Morgan (2014), who operationalized this enhancing effect on fertility by estimating the counterfactual, "What would happen to fertility if all sex preferences were to disappear suddenly?" This

\footnotetext{
${ }^{2} \mathrm{~A}$ recent household survey in Brazil estimated that 1 in each 5 Brazilian women will undergo an abortion before the age of 40 in spite of the prohibition and the deadly consequences of an unsafe abortion (DINIZ; MEDEIROS; MADEIRO, 2016).
} 
counterfactual is estimated by calculating the probability of having a second child given the sex of the first one, and the probability of having a third child giving the sex of the first two.

\section{Replacement effect of child mortality $\left(F_{R}\right)$}

Parents "bear children not for the rewards accruing from the birth itself, but principally for the rewards expected to accrue from surviving children" (PRESTON, 1978, p. 9). Preston (1978) discusses whether improvements in life expectancy and lower infant mortality contributed to the decrease in fertility given that the increase in the probability of survival motivated parents to control fertility. We use Olsen (1980) and Trussell and Olsen (1983)'s technique to estimate (FR), the total replacement effect of child mortality on fertility.

\section{Tempo effect $\left(F_{T}\right)$}

TFR is estimated with data from a specific period (i.e., from women aged 15 to 49 in the same year). If there is a rising age at childbearing, the TFR estimates are lower than otherwise because births of successive cohorts are spread over a longer time period (BONGAARTS, 2001). As Dharmalingam, Rajan and Morgan (2014), we estimated the tempo effect (FT) using Bongaarts and Feeney method. For 1996 and 2006, the annualized rate of change in the mean age at childbearing were calculated using the previous survey. For 1986, however, due to the absence of any prior survey, rate was derived using the same DHS (1986), but using births occurred between 0 to 36 and 36 to 72 months before the survey.

\section{Involuntary infertility $\left(F_{\nu}\right)$}

Involuntary infertility is the effect of the inability to have a child (physiological or disease-induced infecundity), union disruption or the inability to find a suitable partner on fertility. Dharmalingam, Rajan and Morgan (2014) estimates this parameter by looking at the percentage of women in the oldest age group at reproductive age (45-49) who were childless. They did so because motherhood in India is Universal. This is not the case in Brazil and nulliparous women might not know whether they could biologically bear children. Thus, this estimator might not fully represent the involuntary childlessness, but due to data limitations, we estimate involuntary infertility based on the proportion of women aged 40-49 (or 40-44 in 1986) who were or have been previously married or cohabitating and who had never had any child ever born. Ideally, this parameter should also discount the fact that not all women desire children, so many of them could be childless by choice.

\section{Competing preferences $\left(F_{C}\right)$}

Dharmalingam, Rajan and Morgan (2014) set the value of the competing preferences parameter equal to 1 because marriage is universal in India and other life priorities would not influence fertility rates. However, we have enough evidence to believe that Brazilian 
women are feeling pressured by other responsibilities and foregoing maternity more often than in the past.

Following the suggestion of Dharmalingam, Rajan and Morgan (2014), we measured the competing preferences parameter as a residual of equation (1) which cannot be explained by the other five parameters explained above:

$F_{C}=\left(\frac{T F R}{D F S}\right)\left(\frac{1}{F_{U}^{*} F_{S P}^{*} F_{R}{ }^{\star} F_{T}^{*} F_{I}}\right)$

Since marriage is not universal in Brazil and the mean age at first union has been increasing, we then expect this residual to take over positive and increasing values with time. It is important to keep in mind that for being a residual other things might be operating to drive TFR away from DFS.

\section{Socio-economic and demographic groups}

TFR and DFS, as well as the six parameters utilized in the PDLF model, were explored for different population groups separately, which means one equation was estimated for each social group in each year, in an univariate manner. Thus, results need to be interpreted with caution because any change observed could be merely a compositional effect in another social group that was not controlled for. Unfortunately, sample sizes are too small to allow for a multivariate analysis.

Due to the nature of the cross sectional research design, these covariates were measured at the time of the interview, not at the time of birth. There is reason to believe some sociodemographic characteristics might not be stable across lifetime (i.e. upward social mobility due to social policies implemented at the time of the interview). Unable to control for these changes in socioeconomic status, we hoped to minimize them by using two strategies, one for the construction of the wealth index and another one for educational level.

Using Principal Component Analysis, we built a wealth index, which is a 5 -level variable ranging from 0 to 4,4 being the wealthiest category. A wealth index has many advantages over other economic variables because it represents a more permanent status when compared to income or consumption, especially due to fluctuations on income. As suggested by Rutstein and Johnson (2004), the variables chosen to compose the index need to be appropriate for the country's reality.

The education variable is categorical with the following classification: less than Elementary School (0 to 3 years of formal education), Elementary School (4), some or completed Middle School (5 to 8), some or completed High School (9 to 11) and some or completed tertiary education (12 or more). Note, however, that studies involving young subjects or school-age subjects are exposed to a common problem: their incomplete level of education. Predictions were made regarding the final level of education of women aged 15 to 24 based on their age grade distortion and the probability that a woman of the same age and current level of education would finish subsequent education levels using rates 
of grade progression calculated using the Pesquisa Nacional de Amostra de Domicílio PNAD (IBGE, 2017). Details can be made available upon request. Results were very similar to achieved levels so we chose to use this last measure.

Religion might also play a role in differentiating fertility levels. We created a variable with the most numerous groups: Catholics, Protestants or those with no religion at the time of the interview. Although there is a variable for religion conversion in the surveys, which could account for religious mobility, we did not explore this possibility because we did not have the timing at conversion.

Moreover, fertility varies because of regional disparities in cultural and social environments. We included a variable for urbanicity, urban or rural, and another for geographic macro-region of residence, North, Northeast, Southeast, South, or CentralWest (Except for 1986 as previously explained). Fertility levels may vary due to race, and we created a dummy variable, White or Black/Brown (The DHS 1986 did not have a variable for race).

\section{Results}

Recognizing the multiple limitations of our estimates, we highlight that this methodological exercise should be interpreted with care. A descriptive analysis of the sample sizes in each social group can be found in the Supplemental Material (Table 1 in Supplemental Material). In the next paragraphs, we will discuss results for TFR, DFS and the six parameters of the PDLF model. In comparing results for social groups, it is important to bear in mind that all equations are univariate. Future studies should invest in multivariate analysis.

In comparing results for social groups, it is important to keep in mind that all equations are univariate. Future studies should invest in multivariate analysis.

\section{Total fertility rate}

In Brazil, the TFR dropped from 3.21 children per woman in 1986 to 2.49 in 1996 and to 1.87 in 2006, as can be seen in Figure 1 (Table 2 in the Supplemental Material). An analysis of the levels of TFR according to social groups shows that fertility is closely tied to wealth and education. Wealthier and more educated women had lower values for TFR in all years, however, differences have been narrowing. In general, those with higher fertility levels in the beginning of the period were the ones for whom the rates have declined the most, showing a slight convergence.

Moreover, fertility continues to be higher for those who lived in rural areas, who lived in the North and Northeast macro regions, and for Blacks. Those without religious affiliation used to have the highest fertility among religious groups in 1986 , but the values converged in 2006. 
FIGURE 1

Values for TFR and DFS

Brazil - 1986-2006

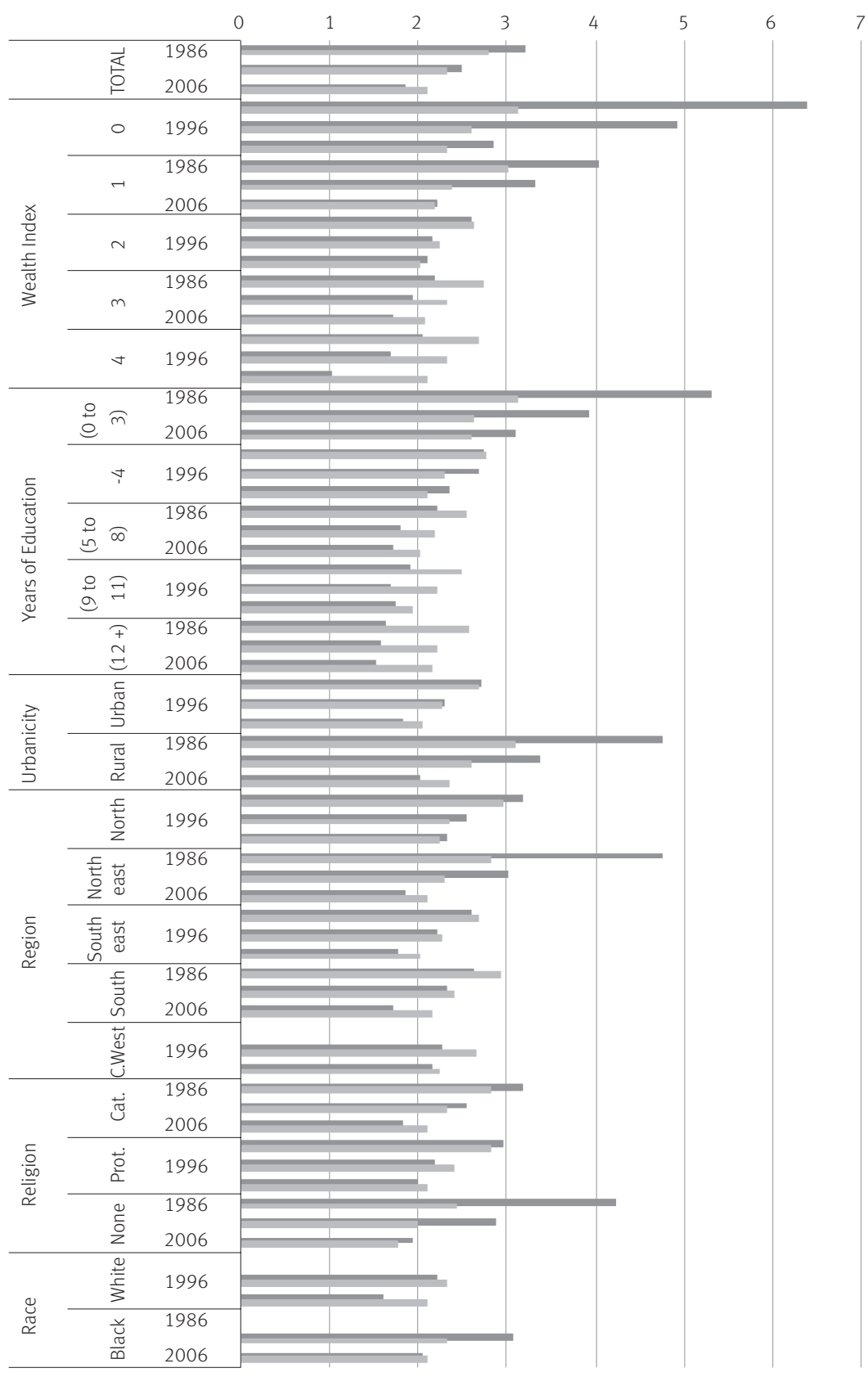

TFR DFS

Source: Demographic and Health Survey (DHS) 1986, 1996; Pesquisa Nacional de Demografia e Saúde (PNDS) 2006. 


\section{Desired family size}

Figure 1 (Table 2 in the Supplemental Material) also shows the results for DFS. There is a clear tendency of DFS decrease between 1986 and 2006, which is possibly the most important driver of the decline in TFR, which fell from 2.79 to 2.10 during the period.

However, the most popular family size continued to be $2: 50 \%$ of all women declared they desired 2 children in 1986 and $43 \%$ did the same in 2006. The percentage who answered 3 children declined from $25 \%$ in 1986 to $16 \%$ in 2006, while those who desired 1 increased from $6 \%$ in 1986 to $17 \%$ in 2006, with those desiring no children increased from $4 \%$ in 1986 to $7 \%$ in 2006 (figures not shown).

Similarly to TFR, although much less steep, DFS declines as wealth and education increase. For example, in 1986 it varied from 3.13 to 2.70 for the wealth level extremes. Put into a time perspective, DFS seem to converge around replacement level: in 2006, the values were 2.34 and 2.11 for these same wealth groups. This is interesting because despite the slight decline, ideal family size is rather stable across time, converging to 2 children as evidence from other countries showing that as TFR declines below replacement level, DFS remains around replacement level (BACHRACH, 2001).

An interesting phenomenon seems to occur for women of the highest levels of wealth and education in 2006 when fertility levels were already below replacement level: they desire more children than some of the less wealth and less educated women. This could be related to expected improvements in income - highly educated women might know they can afford more children, so they want more children. A second hypothesis is that women who proceed to higher education levels have the desire for more children because they are part of a selected group who sees beyond the economic value and costs of children and could be motivated by other ideational reasoning surrounding motherhood (HAKIM, 2003; SHANG; WEINBERG, 2013).

When one looks at their actual fertility rates, however, these women are having fewer children than the other groups. Thus, another explanation is needed to why they end up having a small number of children: wealthier and more educated women might face factors that compete more effectively with childbearing, like career and prolonged education. Estimates for competing preferences, as will be shown later, strengthen this hypothesis: highly educated women have one of the most impacting values for the competing preferences parameters.

The relationship between DFS and urbanicity was as expected. Inhabitants of urban areas not only had fewer children than those in rural areas, but also wished smaller family sizes. This can be explained by the fact that rural areas might have fewer obstacles to have larger families, such as more space, cheaper cost of living, agricultural and familiar work, among others. In a similar vein, Paulo (2012) also found that the motherhood penalty was more severe for mothers in cities than in rural areas 
Macro-region of residence or race does not seem to be an important source of variation for DFS. People without religious affiliation had lower values for DFSs in all years. It is possible that the Christian doctrine "Be fruitful and multiply" is really making a difference regarding family formation by valuing bigger family sizes.

Comparing TFR with DFS, the first thing to be noticed is the fact that there is a reversal for all women between fertility outcome and fertility intentions. That is, TFR is higher than DFS in 1986 and became smaller in 2006, as predicted by Bongaarts (2001), and as expected for Brazilian data, since this is a characteristic of a society undergoing fertility transition. These findings are consistent with Bachrach (2001). Clearly, the reproductive concern of some Brazilian women have changed to not being able to have all the children they have planned.

When comparing the different socio-demographic groups, some tendencies are clear. Poorer, less educated women had many more children than desired in 1986 and by 2006 their TFR approached their DFS, possibly due to a decrease in unwanted births. Conversely, wealthier women who already had DFS smaller than TFR by 1986 fell even further from their desires in 2006. Notice, however, that this last result was not observed for women in the highest level of formal education. These results suggest the existence of distinct competing preferences, one for the pursuit of high levels of human capital and another one for a better economic situation.

Urban and rural areas showed quite different values for the difference between TFR and DFS in 1986, and similar values in 2006. That is, differences between outcomes and intentions seem to be converging between these areas. One of the macro-regions, the Northeast, had a different profile than the others, resembling those of rural areas. A spreading knowledge of fertility control technologies in the most recent surveys may explain these results.

\section{Unwanted fertility}

As the fertility transition advances, with women having better control of their fertility schedules, the value of the parameter is expected to decrease. Indeed, the empirical results show this trend, with values declining from 1.34 to 1.19 for all Brazilian women.

Sadly, the number is decreasing but is still higher for poorer and less educated women, in agreement with Barros and Wong (2012). On the other hand, the parameter for wealthiest and most educated women was around 1.15 in 2006. These results suggest that education and wealth can facilitate access and information about contraception and/or abortion.

Differences between urban and rural areas are not large and in 1986, the parameter in rural areas was larger than in urban regions, with the contrary being observed in 2006. Possibly, relatively to urban areas, rural regions gained more access to resources to implement fertility control, which were already more widespread in cities. 
TABLE 1

Values for parameters of proximate determinants of fertility Brazil - 1986-2006

\begin{tabular}{|c|c|c|c|c|c|c|c|c|c|c|}
\hline \multirow{2}{*}{\multicolumn{2}{|c|}{ Variables }} & \multicolumn{3}{|c|}{ Unwanted fertility } & \multicolumn{3}{|c|}{ Sex preferences } & \multicolumn{3}{|c|}{ Child replacement } \\
\hline & & 1986 & 1996 & 2006 & 1986 & 1996 & 2006 & 1986 & 1996 & 2006 \\
\hline Total & & 1.34 & 1.23 & 1.19 & 1.05 & 1.03 & 1.05 & 1.08 & 1.04 & 1.03 \\
\hline \multirow{5}{*}{$\begin{array}{l}\text { Wealth } \\
\text { index }\end{array}$} & 0 & 1.44 & 1.30 & 1.28 & 1.33 & 1.12 & 1.07 & 1.06 & 1.06 & 1.04 \\
\hline & 1 & 1.41 & 1.27 & 1.18 & 1.25 & 1.04 & 1.13 & 1.06 & 1.05 & 1.02 \\
\hline & 2 & 1.31 & 1.22 & 1.20 & 1.12 & 1.02 & 1.15 & 1.04 & 1.03 & 1.02 \\
\hline & 3 & 1.23 & 1.17 & 1.17 & 1.06 & 1.07 & 1.11 & 1.03 & 1.01 & 1.01 \\
\hline & 4 & 1.15 & 1.15 & 1.15 & 1.06 & 1.05 & 1.07 & 1.02 & 1.01 & 1.01 \\
\hline \multirow{5}{*}{$\begin{array}{l}\text { Years of } \\
\text { education }\end{array}$} & 0 to 3 & 1.44 & 1.33 & 1.26 & 1.08 & 1.19 & 1.25 & 1.08 & 1.05 & 1.04 \\
\hline & 4 & 1.29 & 1.21 & 1.30 & 1.14 & 1.28 & 1.11 & 1.06 & 1.03 & 1.02 \\
\hline & 5 to 8 & 1.26 & 1.20 & 1.18 & 1.28 & 1.28 & 1.06 & 1.04 & 1.03 & 1.01 \\
\hline & 9 to 11 & 1.22 & 1.15 & 1.12 & 1.04 & 1.18 & 1.11 & 1.00 & 1.01 & 1.01 \\
\hline & $12+$ & 1.16 & 1.15 & 1.15 & 1.08 & 1.43 & 1.09 & 1.02 & 1.02 & 1.00 \\
\hline \multirow[t]{2}{*}{ Urbanicity } & Urban & 1.32 & 1.23 & 1.21 & 1.06 & 1.03 & 1.05 & 1.06 & 1.04 & 1.02 \\
\hline & Rural & 1.39 & 1.24 & 1.18 & 1.10 & 1.16 & 1.10 & 1.07 & 1.06 & 1.03 \\
\hline \multirow[t]{5}{*}{ Region } & North & 1.40 & 1.16 & 1.21 & 1.07 & 1.05 & 1.06 & 1.03 & 1.02 & 1.02 \\
\hline & Northeast & 1.43 & 1.26 & 1.20 & 1.24 & 1.18 & 1.11 & 1.09 & 1.06 & 1.05 \\
\hline & Southeast & 1.30 & 1.26 & 1.20 & 1.07 & 1.21 & 1.05 & 1.05 & 1.04 & 1.01 \\
\hline & South & 1.22 & 1.17 & 1.05 & 1.14 & 1.38 & 1.11 & 1.02 & 1.02 & 1.02 \\
\hline & C. West & - & 1.15 & 1.06 & - & 1.38 & 1.14 & - & 1.03 & 1.02 \\
\hline \multirow[t]{3}{*}{ Religion } & Catholic & 1.35 & 1.22 & 1.19 & 1.05 & 1.24 & 1.08 & 1.09 & 1.05 & 1.03 \\
\hline & Protestant & 1.28 & 1.26 & 1.22 & 1.11 & 1.33 & 1.10 & 1.03 & 1.03 & 1.01 \\
\hline & None & 1.38 & 1.28 & 1.23 & 1.29 & 1.17 & 1.09 & 1.06 & 1.10 & 1.01 \\
\hline \multirow[t]{2}{*}{ Race } & White & - & 1.17 & 1.17 & - & 1.30 & 1.09 & - & 1.02 & 1.02 \\
\hline & Black & - & 1.27 & 1.22 & - & 1.18 & 1.05 & - & 1.06 & 1.03 \\
\hline
\end{tabular}

Continued

\begin{tabular}{|c|c|c|c|c|c|c|c|c|c|c|}
\hline \multicolumn{2}{|c|}{ Variables } & \multicolumn{3}{|c|}{ Tempo } & \multicolumn{3}{|c|}{ Involuntary infertility } & \multicolumn{3}{|c|}{$\begin{array}{l}\text { Competing } \\
\text { preferences }\end{array}$} \\
\hline & & 1986 & 1996 & 2006 & 1986 & 1996 & 2006 & 1986 & 1996 & 2006 \\
\hline Total & & 1.08 & 1.00 & 1.05 & 0.95 & 0.96 & 0.94 & 0.74 & 0.84 & 0.70 \\
\hline \multirow{6}{*}{$\begin{array}{l}\text { Wealth } \\
\text { index }\end{array}$} & 0 & 1.06 & 0.97 & 0.95 & 0.97 & 0.97 & 0.91 & 0.97 & 1.31 & 0.99 \\
\hline & 1 & 1.17 & 0.99 & 1.01 & 0.98 & 0.97 & 0.91 & 0.62 & 1.06 & 0.81 \\
\hline & 2 & 1.10 & 1.03 & 0.98 & 0.94 & 0.96 & 0.93 & 0.62 & 0.76 & 0.81 \\
\hline & 3 & 1.18 & 0.97 & 1.03 & 0.92 & 0.97 & 0.93 & 0.55 & 0.70 & 0.67 \\
\hline & 4 & 1.18 & 1.01 & 1.12 & 0.95 & 0.96 & 0.96 & 0.54 & 0.62 & 0.37 \\
\hline & 0 to 3 & 1.05 & 0.95 & 1.08 & 0.97 & 0.97 & 0.95 & 1.00 & 0.98 & 0.72 \\
\hline \multirow{4}{*}{$\begin{array}{l}\text { Years of } \\
\text { education }\end{array}$} & 4 & 1.04 & 1.01 & 0.98 & 0.97 & 0.97 & 0.96 & 0.64 & 0.75 & 0.81 \\
\hline & 5 to 8 & 0.86 & 0.99 & 0.95 & 0.95 & 0.97 & 0.94 & 0.65 & 0.54 & 0.77 \\
\hline & 9 to 11 & 1.14 & 1.11 & 0.92 & 0.88 & 0.95 & 0.94 & 0.60 & 0.52 & 0.83 \\
\hline & $12+$ & 1.37 & 1.35 & 0.84 & 0.83 & 0.91 & 0.92 & 0.44 & 0.34 & 0.73 \\
\hline \multirow[t]{2}{*}{ Urbanicity } & Urban & 1.07 & 0.99 & 1.09 & 0.95 & 0.96 & 0.94 & 0.67 & 0.80 & 0.68 \\
\hline & Rural & 1.07 & 1.01 & 1.02 & 0.96 & 0.96 & 0.93 & 0.91 & 0.87 & 0.68 \\
\hline
\end{tabular}




\begin{tabular}{|c|c|c|c|c|c|c|c|c|c|c|}
\hline \multicolumn{2}{|c|}{ Variables } & \multicolumn{3}{|c|}{ Tempo } & \multicolumn{3}{|c|}{ Involuntary infertility } & \multicolumn{3}{|c|}{$\begin{array}{l}\text { Competing } \\
\text { preferences }\end{array}$} \\
\hline & & 1986 & 1996 & 2006 & 1986 & 1996 & 2006 & 1986 & 1996 & 2006 \\
\hline \multirow{5}{*}{ Region } & North & 1.08 & 0.95 & 1.06 & 0.99 & 0.96 & 0.96 & 0.66 & 0.94 & 0.78 \\
\hline & Northeast & 1.18 & 1.01 & 1.05 & 0.94 & 0.96 & 0.92 & 0.78 & 0.87 & 0.64 \\
\hline & Southeast & 1.03 & 1.02 & 1.02 & 0.94 & 0.97 & 0.93 & 0.68 & 0.63 & 0.73 \\
\hline & South & 0.95 & 1.15 & 1.01 & 0.97 & 0.95 & 0.95 & 0.69 & 0.54 & 0.70 \\
\hline & C.West & - & 0.97 & 1.07 & - & 0.99 & 0.95 & - & 0.54 & 0.77 \\
\hline \multirow{3}{*}{ Religion } & Catholic & 1.06 & 0.99 & 1.06 & 0.95 & 0.97 & 0.94 & 0.72 & 0.72 & 0.66 \\
\hline & Protestant & 1.19 & 1.02 & 1.03 & 0.99 & 0.96 & 0.95 & 0.61 & 0.53 & 0.71 \\
\hline & None & 1.13 & 1.05 & 0.99 & 0.93 & 0.94 & 0.82 & 0.88 & 0.89 & 0.99 \\
\hline \multirow{2}{*}{ Race } & White & - & 1.10 & 1.06 & - & 0.96 & 0.93 & - & 0.58 & 0.59 \\
\hline & Black & - & 1.02 & 1.05 & - & 0.97 & 0.94 & - & 0.84 & 0.75 \\
\hline
\end{tabular}

Source: Demographic and Health Survey (DHS) 1986, 1996; Pesquisa Nacional de Demografia e Saúde (PNDS) 2006.

The differences found in unwanted fertility for different religious groups were small, so the existing differences between TFR and DFS according to religion must come from some other parameter.

Blacks' and Whites' differences have narrowed, although the values are still slightly higher for the former. These results, together with those for poorer and less educated women, could be a result of the reproductive health policies implemented in Brazil during the last decades, such as free distribution of contraceptives, awareness campaigns and even high sterilization rates (CAETANO, 2004). Some of these policies were specially designed to target minorities and low income women in order to spread the knowledge that smaller families are more successful (AMARAL; POTTER, 2015).

\section{Sex preferences}

At national level, desired sex composition of offspring does not seem to significantly impact fertility rates, as estimates are around 1.04 (Table 1). However, the parameter might help explain variations within social groups, although the figures should be observed with caution due to the potential variability caused by small sample sizes of certain parity and composition. The numbers suggest that poorer and less educated women increased their fertility more remarkably due to sex preferences, especially in 1986 and 1996 . This is also the case for women without religious affiliation, Protestants or those living in the Northeast, South or Central-West regions.

\section{Child replacement}

The value for the effect of child mortality and replacement on fertility rates is in decline, and varied from 1.08 in 1986 to 1.03 for all women in 2006 (Table 1). This means that mortality no longer plays an important role in defining fertility level as it did in the recent past. In fact, infant mortality rates in Brazil dropped from 69.2 per thousand in 1986, to 37.5 per thousand in 1996, to 24.9 per thousand in 2006. 


\section{Tempo effect}

Table 1 also brings the values for the parameters tempo effect. Due to its specificities, it is worth remembering that tempo effect in Brazil could help inflate or deflate fertility rates, as the mean age at childbearing has decreased in the past and is now starting to increase.

In average, the Brazilian population in those years was anticipating their fertility, as coefficients are above one. However, it is important to notice that some groups of women, such as those in the lowest level of the wealth index who have young average ages at first child, are in 2006 beginning to postpone - or, to be more specific, they are moving their first child from adolescence to early adulthood. Data also show an inversion in the effects for higher levels of education and women without a religion, as women in these groups started to postpone having children in 2006.

\section{Involuntary infertility}

Notice that the value of the parameters seem to be stable over time and without large differences when all groups are compared (around 0.95). However, for the highly educated and those with no religion, the parameter is smaller. This result shows that this estimate is capturing the effect of another parameter besides biological infertility, as this type of infertility should be similar in all groups or maybe higher for low educated and poorer women (TAVARES et al., 2013). We argue that the parameter is capturing the effect of social infertility, union interruption or inability to find a suitable partner, or even competing preferences. Future steps should be taken to disentangle these effects.

The five parameters discussed so far indicate that unwanted fertility is the most decisive factor among these parameters, while Sex Preferences and the Tempo effect show some idiosyncrasies of the Brazilian society. These parameters have helped elucidate what the main sources of differences regarding TFR and DFS in the three different DHS years among social groups are, but some of the differences remain unexplained.

\section{Competing preferences}

According to Dharmalingam, Rajan and Morgan (2014), it is expected that Competing Preferences are operating where TFR is lower than DFS, as was observed for Brazil in 2006. However, they considered that competition with motherhood was negligible in India, and they set the parameter as a unity (null). Rather differently, in this case values were estimated for the competing preferences $\left(\mathrm{F}_{\mathrm{C}}\right)$ parameters with the residues of equation 1 , or in other words, whatever remained unexplained of the TFR once all estimated parameters were multiplied against the DSF. The results are also presented in Table 1.

Notice the magnitude of the parameters for competing preferences for all women. They are much more negative than all the parameters estimated for the other parameters. That is, competing preferences seem to impact remarkably (and negatively) on fertility levels. 
Observe how the value of the parameter is smaller (again, this means it affects negatively more) for wealthier, for more educated women, and for whites. That is, the pursuit of higher level of formal education and of a better insertion in the labor market seems to effectively compete with motherhood.

Residents of urban areas had lower values for the competing preferences parameter than those in rural areas, possibly because having a child in cities implies higher costs, including opportunity costs. Notice, however, that differences in 2006 were decreasing. This and other results already presented indicate a convergence between urban and rural areas in socio cultural aspects linked to fertility.

Concerning macro-regions, the value for the North region was slightly higher than in other regions, indicating smaller impacts of competing preferences on fertility. The same was observed for the group with no religion.

In order to test whether the residual, hereby called competing preference, is indeed associated with variables representing a competition against motherhood, we plotted the competing preferences parameter for each social-demographic group against the average level of achieved formal education for the same socio-demographic group, in the three years analyzed. As mentioned, one of the most common competing factors to motherhood is the pursuit of higher levels of formal education. Figures 2 to 4 shows the results for the years of 1986, 1996 and 2006. All three years present a negative correlation between residual and average level of education, as expected. Notice, however, how the relationship has become flatter in 2006 with a much smaller $\mathrm{R}^{2}$. This factor means that education attainment has become less competitive with fertility over time, possibly because education attainment might have become less selective as more women are achieving higher levels of education.

Other factors, such as labor market insertion and the pursuit for a suitable partner may be playing a larger role. These topics deserve future research, but this is beyond the scope of this paper.

FIGURE 2

Scatterplot of the competing preferences values with the population mean values for years of education, all socio-demographic groups Brazil - 1986

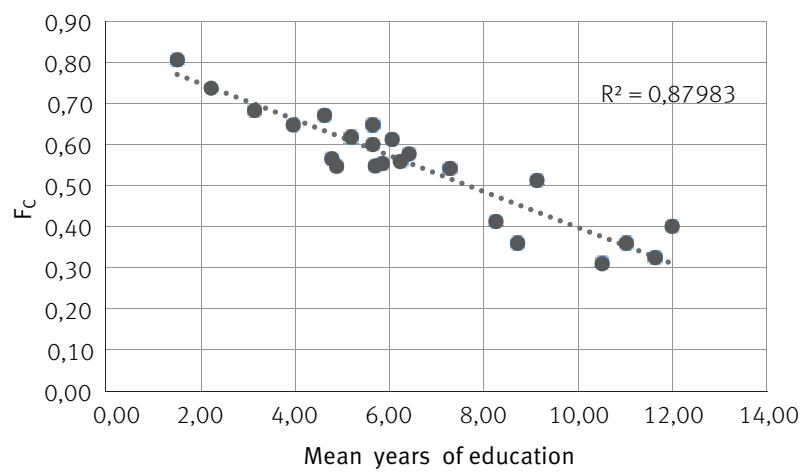

Source: Demographic and Health Survey (DHS) 1986. 
FIGURE 3

Scatterplot of the competing preferences values with the population mean values for years of education, all socio-demographic groups

Brazil - 1996

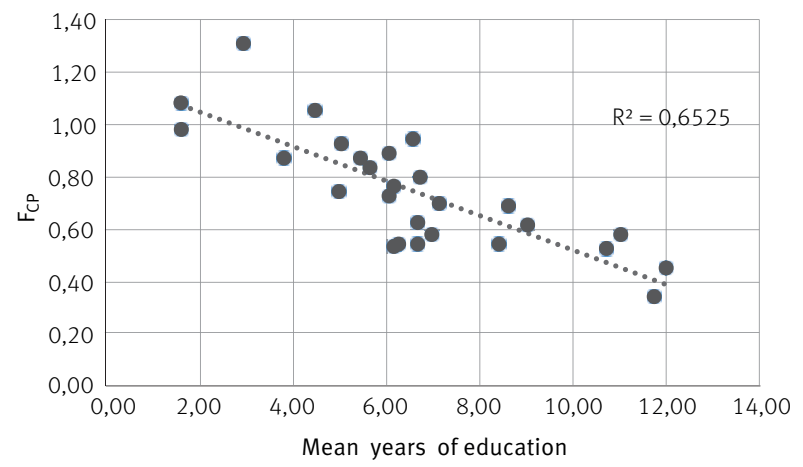

Source: Demographic and Health Survey (DHS) 1996.

FIGURE 4

Scatterplot of the competing preferences values with the population mean values for years of education, all socio-demographic groups Brazil-2006

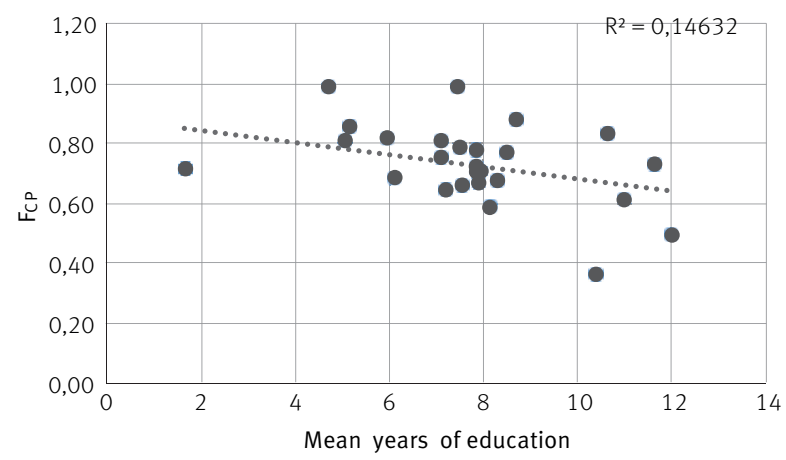

Source: Pesquisa Nacional de Demografia e Saúde (PNDS) 2006.

\section{What factors/parameters explain TFR?}

In order to check which of the parameters explain most of the variance in TFR, we performed an OLS regression for each year with the socio-demographic groups as unit of analysis. The dependent variable was the TFR. The explanatory variables were introduced in the models one by one in the following order: DFS, unwanted fertility $\left(\mathrm{F}_{\mathrm{U}}\right)$, sex preference $\left(\mathrm{F}_{\mathrm{SP}}\right)$, replacements for child mortality $\left(\mathrm{F}_{\mathrm{R}}\right)$, Tempo effect $\left(\mathrm{F}_{\mathrm{T}}\right)$, involuntary infertility $\left(\mathrm{F}_{\mathrm{I}}\right)$, and competing preferences $\left(\mathrm{F}_{\mathrm{C}}\right)$. The amount of variance explained by each model was estimated. Table 2 shows the results for $\mathrm{R}^{2}$ for each model. By construction, competing preferences is the residual of the model and hence the variance is totally explained with all parameters when competing preferences are included. 
TABLE 2

Explained variance for OLS models according to the parameters of the Bongaarts equation as sets of explanatory variables

Brazil - 1986-2006

\begin{tabular}{cccc}
\hline Model & 1986 & 1996 & 2006 \\
\hline$D F S$ & 0.573 & 0.387 & 0.459 \\
$D F S+F_{u}$ & 0.848 & 0.788 & 0.694 \\
$D F S+F_{u}+F_{s p}$ & 0.882 & 0.794 & 0.727 \\
$D F S+F_{u}+F_{s p}+F_{r}$ & 0.883 & 0.852 & 0.740 \\
$D F S+F_{u}+F_{s p}+F_{r}+F_{t}$ & 0.891 & 0.858 & 0.740 \\
$D F S+F_{u}+F_{s p}+F_{r}+F_{t}+F_{i}$ & 0.907 & 0.867 & 0.741 \\
$D F S+F_{u}+F_{s p}+F_{r}+F_{t}+F_{i}+F_{C}$ & 1.000 & 1.000 & 1.000 \\
\hline
\end{tabular}

Source: Demographic and Health Survey (DHS) 1986, 1996; Pesquisa Nacional de Demografia e Saúde (PNDS) 2006.

Indeed, the desired family size explains much of the variance in TFR. After DFS, Unwanted Fertility adds the most for the predictive power of the models. Notice that these two parameters explained together $0.85,0.79$ and 0.69 of the variance in 1986, 1996 and 2006 respectively. Sex Preference, Replacements for Child Mortality, Tempo effect and Involuntary Infertility contributed less, but still added to the explanatory power. Note how the importance of the residual (hereby classified as Competing Preference) grows over time - which means over time the first five factors are explaining less of the variation. Thus, all parameters seem to contribute for the explanation of TFR, which suggests that the PDLF framework proposed by Bongaarts (2001) and the methodology proposed by Dharmalingam, Rajan and Morgan (2014) works well for Brazilian data.

\section{Conclusion}

We decompose Brazilian fertility rates in 1986, 1996 and 2006 using a framework devised by Bongaarts (2001), and previously modeled by Dharmalingam, Rajan and Morgan (2014) using data from India. We modified the methodology proposed by these last authors in order to adjust it to the Brazilian reality, as we recognize the framework is unable to capture the full complexity of the Brazilian reality. Nevertheless, we were able to learn the contribution of each parameter for overall fertility composition, and how those parameters changed when fertility became smaller than desired family sizes. We were also able to capture some new insights, as the role of competing preferences in reducing the fertility rates, which wasn't considered when this model was applied for India.

Fertility in Brazil is declining quickly and has been below replacement level since around 2000. The desired number of children is also declining, albeit less remarkably, and can be considered one of the main factors behind the decline of TFR.

In the period between 1986 and 2006, a qualitative change in fertility occurred in Brazil. Previously, women used to have more children than desired and recently they have fewer. Besides, in the recent past, women who attained higher levels of formal education desired having less children than less educated women and nowadays women who have 
proceeded to higher levels of education desire more children. These two aspects suggest that the transition to very low levels of fertility has some idiosyncrasies in Brazil.

Among the six factors of the PDLF, unwanted fertility is still the factor that most produces a surplus of children. However, its relative importance decreased in the years analyzed. Unwanted fertility continues to be lower for the highly educated and wealthier women. Further increases in economic development and education levels could reduce unwanted fertility, and drop fertility rates even more.

The relationship between fertility rates and postponement (tempo effect) is a complex one. While it was possible to observe postponements in childbearing, especially for groups for which fertility was very low, we could also observe a decrease in the mean age at births for different parities.

Competing preferences also seem to be an important factor behind women not achieving their desired number of children, especially women of higher education, and the size of this parameter has been increasing over time. Literature suggests that these trends are associated with sociodemographic changes in Brazil, such as modernization, urbanization, general increase in schooling levels, increase in the participation of females in the labor force, among others, which could be another sign that fertility could go even lower, as the process continues in the future.

One important limitation of the PDLF framework is the fact that it is not immune to compositional effects in fertility rates that could have been caused by an average increase in education level during the period or even an age and cohort effects (the fact that younger women are in general more educated and have less children than their older counterparts in all cohorts). Future analysis and decomposition should embrace these possibilities. Moreover, effects of the middle class expansion and relevant public policies, such as cash transfers and increasing opportunities of college admission by means of education quotas for more socially disadvantaged youth and their impact on fertility rates (RIOS-NETO, 2005), deserve further investigation.

Nevertheless, the framework devised by Bongaarts (2001) and the methodology proposed by Dharmalingam, Rajan and Morgan (2014) enabled us to advance in the analysis of competing preferences, as it allowed us to estimate competition to fertility as a residual. The authors are currently looking into exploring this parameter even further, and shed light on the reasons why women are revising their reproductive goals. At least two major explanations are present in the literature and should be considered: women who forego or postpone motherhood in order to pursue life goals or due to systematic social constrains, such as lack of affordable childcare or discrimination against mothers in the workplace.

It is also important to say that abortion is highly restricted in Brazil, but estimates from surveys indicate that at the end of reproductive life, one in five women have had an abortion (DINIZ; MEDEIROS, 2010). To estimate unwanted fertility, however, it is not necessary to know abortion rates or rates of contraceptive use. For future work, we recommend these factors be explored. 
Demographers could also use the PDLF model to predict how changes in a certain population parameter could affect fertility, as existing TFR is not only a change in preference in ideal family sizes, but an inability of women to deter unwanted birth or fulfill their reproductive expectations. Thus, policy makers should look at the necessities of different groups to design and implement better policies focusing on reproductive goals. This useful framework has proven valuable to understand variation in transition and post-transition fertility in Brazil, especially in a context where competition and constrains are real. Besides, the model can serve as basis for further empirical enquires.

To conclude, it is important to keep in mind that we are assuming all woman would want to have the number of children they report as ideal, but this is not necessarily true as women may just report what they consider to be "the ideal", but not the "target" fertility (MORGAN; RACKIN, 2010). More research is necessary in terms of what models fertility intentions and outcomes and how women navigate their dreams and desires during the course of their lives and the (un)expected conjunctures surrounding their attitudes and behaviors, such as the appearance of new life goals, romantic partnerships, family members' traditions and expectations, cultural norms, workplace environment, among many others. In that regard, we reinforce the necessity of conducting longitudinal analysis at the individual level.

\section{References}

ALVES, J.; CAVENAGHI, S. Timing of childbearing in below replacement fertility regimes: how and why Brazil is different. In: XXVI IUSSP INTERNATIONAL POPULATION CONFERENCE. Proceedings... Marrakech, Morocco, 2009. Available at: 〈http://iussp2009.princeton.edu/papers/92527〉.

AMARAL, E.; POTTER, J. Determinants of female sterilization in Brazil, 2001-2007. RAND Labor and Population, 2015 (RAND Working Paper Series WR-1093). Available at: 〈https://www.rand. org/content/dam/rand/pubs/working_papers/WR1000/WR1093/RAND_WR1093.pdf〉.

BACHRACH, C. Comment: the puzzling persistence of postmodern fertility preferences. Population and Development Review, v. 27 (Suppl Global Fertility Transition), p. 332-338, 2001.

BACHRACH, C. A.; MORGAN, S. P. A cognitive-social model of fertility intentions. Population and Development Review, v. 39, n. 3, p. 459-485, 2013.

BACCI, M. L. Comment: Desired family size and the future course of fertility. Population and Development Review, v. 27 (Supplement: Global Fertility Transition ), p. 282-289, 2001.

BARROS, J.; WONG, L. Prevalência, conhecimento e tipos de métodos contraceptivos utilizados pelas mulheres, segundo o tipo de união: um estudo para Brasil e México. In: XVIII ENCONTRO NACIONAL DE ESTUDOS POPULACIONAIS. Anais... Águas de Lindóia: Abep, 2012. Available at: 〈http://www.abep.org.br/publicacoes/index.php/anais/article/view/1950/1908〉.

BERQUO, E.; GARCIA, S.; LIMA, L. Reprodução na juventude: perfis sociodemográficos, comportamentais e reprodutivos na PNDS 2006. Revista de Saúde Pública, v. 46, n. 4, p.685693, 2012.

BEMFAM. DHS final reports. Brazil DHS, 1986. Rio de Janeiro: Macro International Inc., 1987.

DHS final reports. Brazil DHS, 1996. Rio de Janeiro: Macro International Inc., 1997. 
BHUSHAN, I.; HILL, K. The measurements and interpretation of desired fertility. 1995 (Hopkins Population Center Working Paper Archive, WP95-01). Available at: 〈http://jhir.library.jhu.edu/ handle/1774.2/953>.

BONGAARTS, J. A framework for analyzing the proximate determinants of fertility. Population and Development Review, v. 4, n. 1, p. 105-132, 1978.

Fertility and reproductive preferences in post-transitional societies. Population and Development Review, v. 27 (Supplement: Global Fertility Transition), p. 260-281, 2001.

The implementation of preferences for male offspring. Population and Development Review, v. 39, n. 2, p. 185-208, 2013.

BONGAARTS, J.; POTTER, R. Fertility, biology and behavior. New York: Academic Press, 1983.

BRASIL. Ministério da Saúde. Pesquisa Nacional de Demografia e Saúde da Mulher e da Criança PNDS 2006. Relatório final. Brasília/DF: Cebrap, 2008.

BRASIL. Ministério da Saúde; CEBRAP. Pesquisa Nacional de Demografia e Saúde da Criança e da Mulher - PNDS 2006: dimensões do processo reprodutivo e da saúde da criança. Brasília, 2009. Available at: 〈http://bvsms.saude.gov.br/bvs/publicacoes/pnds_crianca_mulher.pdf〉.

CAETANO, A. O declínio da fecundidade e suas implicações: uma introdução. In: CAETANO, A.; ALVES, J.; CORRÊA, S. (Ed.). Dez anos do Cairo: tendências da fecundidade e direitos reprodutivos no Brasil. Campinas: Abep e UNFPA, 2004. p. 11-19.

CARVALHO, J.; BRITO, F. A demografia brasileira e o declínio da fecundidade no Brasil: contribuições, equívocos e silêncios. Revista Brasileira de Estudos de População, v. 22, n. 2, p. 351-369, 2005.

CAVENAGHI, S. M. Aspectos metodológicos e comparabilidade com pesquisas anteriores. In: BRASIL. Ministério da Saúde; CEBRAP (Org.). Pesquisa Nacional de Demografia e Saúde da Criança e da Mulher PNDS 2006: dimensões do processo reprodutivo e da saúde da criança. Brasília, 2009. v. 1, p. 13-32.

CAVENAGHI, S. M.; BERQUÓ, E. Perfil socioeconômico e demográfico da fecundidade no Brasil de 2000 a 2010. In: CAVENAGHI, S.; CABELLA, W. Comportamiento reproductivo y fecundidad en América Latina: una agenda inconclusa. Rio de Janeiro: Alap, 2015. p. 220-240.

CLELAND, J.; MOHAMED, A. Reproductive consequences of contraceptive failure in 19 developing countries. Obstetrics \& Gynecology, v. 104, n. 2, p. 314-320, 2004.

COUTINHO, R. Z. The transition to low fertility in Brazil. Tese (Doctor of Philosophy in the Sociology) -The University of North Carolina at Chapel Hill, 2016.

CURTIS, S. Contraceptive use dynamics research needs post fertility transition. Revista Brasileira de Estudos de População, v. 29, n. 1, p. 191-193, 2012.

DAVIS, K.; BLAKE, J. Social structure and fertility: an analytic framework. Economic Development and Cultural Change, v. 4, n. 3, p. 211-235, 1956.

DHARMALINGAM, A.; RAJAN, S.; MORGAN, P. The determinants of low fertility in India. Demography, v. 51, n. 4, p. 1451-1475, 2014.

DIAS JR., C. S. Comportamento reprodutivo das mulheres trabalhadoras urbanas brasileiras. In: XVI ENCONTRO NACIONAL DE ESTUDOS POPULACIONAIS. Anais... Caxambu-MG: Abep, 2008. Available at: 〈http://www.abep.org.br/publicacoes/index.php/anais/article/view/1834/1793〉.

DINIZ, D.; MEDEIROS, M. Aborto no Brasil: uma pesquisa domiciliar com técnica de urna. Ciência \& Saúde Coletiva, v. 15(Supl. 1), p. 959-966, 2010. 
DINIZ, D.; MEDEIROS, M.; MADEIRO, A. Pesquisa Nacional de Aborto 2016. Ciência \& Saúde Coletiva, v. 27, n. 2, p. 653-660, 2017.

HAKIM, C. A new approach to explaining fertility patterns: preference theory. Population and Development review, v. 29, n. 3, p. 449-374, 2003.

IBGE - Instituto Brasileiro de Geografia e Estatística. Censo Demográfico 2010: resultados gerais da amostra. Rio de Janeiro, 2012. Available at: 〈http://www.ibge.gov.br/home/presidencia/ noticias/imprensa/ppts/00000008473104122012315727483985.pdf〉.

Pesquisa Nacional por Amostra de Domicílios. Bases disponíveis em: <https:// ww2.ibge.gov.br/home/estatistica/pesquisas/anos_anteriores.shtm>. Acesso em: 11 dez. 2017.

ITABORAÍ, N. Trabalho feminino e mudanças na família no Brasil (1984-1996): explorando relações. Revista Brasileira de Estudos de População, v. 20, n. 2, p. 157-176, 2003.

LACERDA, M. et al. Mensuração e perfis de demanda insatisfeita por contracepção nos municípios de Belo Horizonte e Recife, 2002. Revista Brasileira de Estudos de População, v. 22, n. 1, p. 113-129, 2005.

MASON, K. Explaining fertility transitions. Demography, v. 34, n. 4, p. 443-454, 1997.

MIRANDA-RIBEIRO, A.; RIOS-NETO, E. L. G.; CARVALHO, J. A. M. Efeitos tempo, parturição e quantum no Brasil: indicadores de período e evidências empíricas. Revista Brasileira de Estudos de População, v. 30, n. 1, p. 145-170, jan./jun. 2013.

MIRANDA-RIBEIRO, A.; GARCIA, R. Transições da fecundidade no Brasil: uma análise à luz dos diferenciais por escolaridade. In: XVIII ENCONTRO NACIONAL DE ESTUDOS POPULACIONAIS. Anais... Águas de Lindóia-SP: Abep, 2012. Available at: 〈http://www.abep.nepo.unicamp.br/ xviii/anais/files/400.pdf〉.

MIRANDA-RIBEIRO, A.; ORTEGA, J.; RIOS-NETO, E. Efeito tempo, quantum e efeito parturição na transição da fecundidade no Brasil: aplicação do modelo de Köhler \& Ortega. In: XV ENCONTRO NACIONAL DE ESTUDOS POPULACIONAIS. Anais... Caxambu-MG: Abep, 2006. Available at: 〈http:// www.abep.nepo.unicamp.br/encontro2006/docspdf/ABEP2006_262.pdf〉.

MORGAN, P.; ZHIGANG, G.; HAYFORD, S. China's below replacement fertility: recent trends and future prospects. Population and Development Review, v. 35, n. 3, p. 605-630, 2009.

MORGAN, P. Is low fertility a twenty-first-century demographic crisis? Demography, v. 40, n. 4, p. 589-603, 2003.

MORGAN, S. P.; RACKIN, H. The correspondence between fertility intentions and behavior in the United States. Population and Development Review, v. 36, n. 1, p. 91-118, 2010.

MYRSKYLA, M.; KOHLER, H.; BILLARI, F. Advances in development reverse fertility declines. Nature, n. 460, p. 741-743, 2009. Available at: 〈https://search-proquest.ez27.periodicos.capes.gov.br/ docview/204539863/fulltext/71F56EA5744646A4PQ/1?accountid=134127>.

. High development and fertility: fertility at older reproductive ages and gender equality explain the positive link. Max Planck Institute for Demographic Research, 2011 (MPIDR Working Paper WP 2011-017). Available at: 〈http://www.demogr.mpg.de/papers/working/wp2011-017.pdf〉.

OLSEN, R. Estimating the effect of child mortality on the number of births. Demography, v. 17, n. 4, p. 429-443, 1980.

PAULO, M. Uma análise do diferencial de salários entre as mulheres que são mães e aquelas que não são mães, e entre aquelas que postergam e não postergam a fecundidade no período entre 1984 a 2009. In: XVIII ENCONTRO NACIONAL DE ESTUDOS POPULACIONAIS. Anais... Águas 
de Lindóia: Abep, 2012. Available at: 〈http://www.abep.org.br/publicacoes/index.php/anais/ article/view/2017/1975>.

POTTER, J. et al. Mapping the timing, pace, and scale of the fertility transition in Brazil. Population and Development Review, v. 36, n. 2, p. 283-307, 2010.

PRESTON, S. The effects of infant and child mortality on fertility. New York: Academic Press, 1978.

QUESNEL-VALLEE, A.; MORGAN, S. P. Missing the target? Correspondence of fertility intentions and behavior in the U.S. Population Research and Policy Review, v. 22, n. 5-6, p. 497-525, 2003.

RAY, C.; HARCEY, S.; TIEMEYER, S. What's ideal got to do with it? Stability and change in ideal number of children. In: EUROPEAN POPULATION CONFERENCE. Proceedings... Mainz, Alemanha, 2016.

RIOS-NETO, E. Questões emergentes na análise demográfica: o caso brasileiro. Revista Brasileira de Estudos de População, v. 22, n. 2, p. 371-408, 2005.

RIOS-NETO, E. L. G.; SILVA, V.C.; MIRANDA-RIBEIRO, A.; ORTEGA, J. A.; CARVALHO, J. A. M. Fertility decline in Brazil: a different tempo effect with strong consequences. In: PAA ANNUAL MEETING. Proceedings... Philadelphia, Pennsylvania: Population Association of America, 2005. Available at: 〈http://paa2005.princeton.edu/papers/50286〉.

RUTSTEIN, S.; JOHNSON, K. The DHS Wealth Index. DHS Comparative Reports n. 6. Calverton, Maryland: ORC, 2004.

RYBINSKA, A. Family size preferences in early adulthood: measurement error and dimensionality. In: EUROPEAN POPULATION CONFERENCE. Proceedings... Mainz, Alemanha, 2016.

SHANG, Q.; WEINBERG, B. Opting for families: recent trends in the fertility of highly educated women. Jornal of Population Economics, v. 26, n. 1, p. 5-32, 2013.

SOUZA, L.; RIOS-NETO, E.; QUEIROZ, B. A relação entre parturição e trabalho feminino no Brasil. Revista Brasileira de Estudos de População, v. 28, n. 1, p. 57-79, 2011.

TAVARES, L. S.; LEITE, I. C.; NORONHA, M. F.; RODRIGUES, R. N.; CUNHA, G. M.; VALENTE, J. G.; SCHARAMM, J. M. A.; COSTA, M. F. S. Diferenciais da carga de doença das condições maternas entre mulheres de 15 a 44 anos no Estado de Minas Gerais, 2004-2006. Revista Brasileira de Estudos de População, v. 30, Sup., p. S119-S134, 2013.

TRUSSELL, J.; OLSEN, R. Evaluation of the Olsen technique for estimating the fertility response to child mortality. Demography, v. 20, n. 3, p. 391-405, 1983.

UNITED NATIONS. Department of Economic and Social Affairs, Population Division. World population prospects: The 2017 revision. 2017.

VIEIRA, J.; ALVES, L. O comportamento da idade média à união e ao casamento no Brasil em 2000 e 2010. Revista Latinoamericana de Poblacion, Año 10, n. 19, p. 107-126, 2016.

VIGNOLI, J. R.; CAVENAGHI, S. Unintended fertility among Latin American adolescents: a growing trend across all socioeconomic groups. In: XXVIII INTERNATIONAL UNION FOR THE SCIENTIFIC STUDY OF POPULATION. Proceedings... Cape Town, South Africa, 2017.

\section{About the authors}

Raquel Zanatta Coutinho holds a Ph.D in Sociology from the University of North Carolina in Chapel Hill (USA). She is an Assistant Professor at the Demography Department of Universidade Federal 
Minas Gerais (UFMG) and a researcher at the Centro de Desenvolvimento e Planejamento Regional (Cedeplar) of UFMG.

André Braz Golgher holds a Ph.D in Demography from Centro de Desenvolvimento e Planejamento Regional (Cedeplar) of Universidade Federal de Minas Gerais (UFMG). He is an Associate Professor at the Economics Department of UFMG and is a researcher at the Centro de Desenvolvimento e Planejamento Regional (Cedeplar) of UFMG.

\title{
Contact address
}

\author{
Raquel Zanatta Coutinho \\ Cedeplar - Centro de Desenvolvimento e Planejamento Regional \\ Faculdade de Ciências Econômicas - 3ํandar \\ Av. Antônio Carlos, 6627 - Pampulha \\ 31270-901 - Belo Horizonte-MG, Brazil \\ Andre Braz Golgher \\ Cedeplar - Centro de Desenvolvimento e Planejamento Regional \\ Faculdade de Ciências Econômicas - 3으 andar \\ Av. Antônio Carlos, 6627 - Pampulha \\ 31270-901 - Belo Horizonte-MG, Brazil
}

\section{Resumen}

Modelando los determinantes proximos de la fecundidad para Brasil: el avance de las preferencias competitivas

Más de la mitad de los habitantes del mundo vive en un pais donde la fecundidad está abajo del nivel de reposición (MYRSKYLA; KOHLER; BILLARI, 2009). En Brasil, la tasa global de fecundidad (TGF) fue reducida de 4.26 hijos por mujer en 1980 para 1.91 en 2010. Existen algunas disparidades internas. Utilizamos datos del DHS de 1986, 1996 y del PNDS de 2006, el estudio más reciente disponible, para descomponery analizar las tasas de fecundidad utilizando un método propuesto por Bongaarts (2001), el cual es especialmente útil para explorary comparar los factores por detrás de las tasas globales de fecundidad. El método incluye el tamaño deseado de familia, fecundidad indeseada, preferencia de sexo, reposición de la mortalidad infantil, el aumento de la edad al primero hijo, infecundidad involuntaria y preferencias competitivas. Al comprender la variación de la fecundidad y sus componentes através del tiempo en Brasil, este artículo ilumina como esos factores varían de acuerdo con características socio-demograficas (raza, religión, riqueza, educación y sitio de residencia) y como esos factores combinados han formado la TFR a lo largo de los años y en el contexto de alta y baja fecundidad. Encontramos que contrariamente al pasado, mujeres en periodos más recientes tienen, al todo, menos hijos que los que compondrían su tamaño deseado de familia. Sin embargo, embarazos indeseados aún son responsables por que algunos grupos sociales tengan más hijos que los que desean. También encontramos que mujeres con niveles más altos de educación tienden a desear tener más hijos que las mujeres con niveles más bajos. Las preferencias competitivas son la explicación principal para esa incompatibilidad.

Palabras clave: Fecundidad abajo del nivel de reposición. Descomposición. Determinantes immediatos. Brasil. 


\section{Resumo}

Modelando os determinantes próximos da fecundidade para o Brasil: o advento das preferências competitivas

Mais da metade dos habitantes do planeta vive em um país onde a Taxa de Fecundidade Total (TFT) está abaixo do nível de reposição (MYRSKYLA; KOHLER; BILLARI, 2009). No Brasil, a TFT caiu de 4,26 filhos por mulher, em 1980, para 1,91, em 2010. Existem, no entanto, disparidades internas. No presente trabalho, são utilizados dados da DHS de 1986, 1996 e da PNDS de 2006, o estudo mais recente disponível, que permitem decompor e analisar taxas de fecundidade empregando o método proposto por Bongaarts (2001), o qual é especialmente útil para explorar e comparar os fatores que compõem a TFT. 0 método inclui o tamanho desejado de família, a fecundidade indesejada, a preferência por sexo, a reposição da mortalidade infantil, o aumento da idade ao primeiro filho, a infertilidade involuntária e as preferências competitivas. Ao compreender a variação da fecundidade e seus componentes ao longo do tempo no Brasil, esse artigo explora como tais fatores variam de acordo com as características sociodemográficas (raça/cor, religião, nível de riqueza, educação e local de residência) e como esses fatores combinados formaram a TFT ao longo dos anos e nos contextos de alta e baixa fecundidade. Observou-se que mulheres nos períodos mais recentes têm, em média, menos filhos do que poderiam ter segundo seu tamanho ideal de família. Ao mesmo tempo, gravidezes indesejadas ainda são responsáveis por alguns grupos sociais terem mais filhos do que desejavam. Também verificou-se que mulheres com níveis mais altos de educação tendem a desejar mais filhos do que aquelas com nível mais baixo. As preferências competitivas são a explicação principal para essa incompatibilidade.

Palavras-chaves: Fecundidade abaixo da reposição. Decomposição. Determinantes próximos. Brasil. 